Etikonomi

Volume 14 (1), April 2015

P-ISSN: 1412-8969; E-ISSN: 2461-0771

Halaman 35 - 50

\title{
PENGARUH KOMITMEN ORGANISASI, PENGHARGAAN DAN KEPUASAN KERJA TERHADAP PERPUTARAN KARYAWAN PADA PERBANKAN SYARIAH Di KOTA BATAM
}

\author{
Ahmad Zulva Adi \& Sri Langgeng Ratnasari \\ Fakultas Ekonomi Universitas Batam \\ zulvabnis@gmail.com; sarisucahyo@yahoo.com
}

\begin{abstract}
.
This study aims to analyze the effect of organizational commitment, reward to turn-over intention through work satisfaction variable and to analyze the most affective variable on turn-over intention. The method that used on this study is path analysis. According to the analysis, it is concluded as the followings: organizational commitment has an effect on work satisfaction, reward has an effect on work satisfaction, work satisfaction has an effect on turnover intention, organizational commitment has an effect on turnover intention, reward has an effect on turnover intention, organizational commitment has an effect on turnover intention through work satisfaction, reward has an effect on turnover intention through work satisfaction.
\end{abstract}

Keywords : turn-over intention; path analysis; work satisfaction

\begin{abstract}
Abstrak.
Kajian ini bertujuan untuk menganalisis pengaruh komitmen organisasi, penghargaan terhadap perputaran karyawan melalui variabel kepuasan kerja, dan untuk menganalisis variabel yang paling mempengruhi perputaran karyawan. Metode yang dipergunakan dalam penelitian ini adalah analisis lajur. Berdasarkan analisis yang dilakukan dapat disimpulkan bahwa komitmen organisasi memiliki pengaruh terhadap kepuasan kerja, penghargaan memiliki pengaruh terhadap kepuasan kerja, kepuasan kerja memiliki pengaruh terhadap perputaran karyawan, komitmen organisasi memiliki pengaruh terhadap perputaran karyawan, penghargaan memiliki pengaruh terhadap perputaran karyawan, komitmen organisasi memiliki pengaruh terhadap perputaran karyawan melalui kepuasan kerja, penghargaan memiliki pengaruh terhadap perputaran karyawan melalui kepuasan kerja.
\end{abstract}

Kata Kunci: intensitas perputaran; analisis lajur; kepuasan kerja

Diterima: 15 Januari 2015; Direvisi: 22 Februari 2015; Disetujui: 2 Maret 2015 


\section{PENDAHULUAN}

Bank adalah badan usaha yang menghimpun dana dari masyarakat dalambentuk simpanan dan menyalurkannya kepada masyarakat dalam bentuk kreditdan atau bentuk-bentuk lainnya dalam rangka meningkatkan taraf hidup rakyat banyak (Undang-undang nomor 7 tahun 1992 tentang perbankan sebagaimana telah diubah dengan Undang-undang nomor No. 10 Tahun 1998). Terkait dengan perbankan syariah, pada Juli 2008 telah disahkan UndangUndang No. 21 Tahun 2008 yang khusus mengatur tentang Perbankan Syariah. Hal ini sebagai landasan hukum agar pengembangan industri perbankan syariah di Indonesia dapat lebih cepat.

Perbankan syariah menunjukkan perkembangannya yang impresif, dengan pertumbuhan aset rata-rata selama 5 tahun terakhir lebih dari $46 \%$ pertahun (Bank Indonesia, 2012). Berdasarkan data Statistik Perbankan Syariah (Bank Indonesia, 2012), total aset industri perbankan syariah per akhir Februari 2012 telah mencapai Rp149,32 triliun, total pembiayaan yang disalurkan sebesar Rp106,53 triliun, DanaPihak Ketiga Rp116,87 triliun dan jumlah kantor 2.380 kantor, yang terdiri dari 1.421 kantor Bank Umum Syariah (BUS), 378 kantor Unit Usaha Syariah (UUS)dan 374 kantor Bank Pembiayaan Rakyat Syariah (BPRS).

Namun demikian, pertumbuhan perbankan syariah yang cukup tinggi tersebut mengalami masalah minimnya sumber daya manusia (SDM), baik secara kuantitas maupun kualitas untuk mendukung pertumbuhan industri lebih lanjut. Dalam kenyataannya, permintaan SDM perbankan syariah cukup tinggi untuk perluasan jaringan usaha, operasional bank syariah dan kebutuhan SDM di level manajemen. Sementara itu, pola rekrutmen SDM di perbankan syariah cenderung merekrut SDM-SDM diantara sesama bank syariah yang berkualitas dan sudah berpengalaman dan juga merekrut SDM-SDM baru yang tidak memiliki latar belakang pengetahuan maupun ilmu perbankan syariah. Kondisi ini mengakibatkan bank syariah menjadi kurang kompetitif, pemenuhan SDM perbankan syariah tetap tidak dapat terpenuhi dan sering terjadi kekurangan SDM berkualitas di beberapa bank syariah. 
Akibat adanya selisih atau gap antara permintaan dan penawaran ini,pertumbuhan industri perbankan syariah berpotensi akan mengalami kendala, antara lain:

1. Operasional bank syariah yang semakin kompleks tidak berkembang karena SDM belum memiliki keahlian dan pengetahuan yang handal tentang keuangan syariah.

2. Ekspansi usaha yang membutuhkan SDM yang tinggi tidak dapat terealisasikarena tidak didukung SDM yang memiliki latar belakang keuangan syariah.

3. Pemenuhan SDM di masing-masing level (lower, middle maupun top management) tidak terpenuhi.

Oleh karena itu studi ini melakukan suatu analisis terhadap masalah SDM perbankan syariah khususnya strategi pemenuhan kebutuhan SDM perbankan syariah. Hasil kajian penelitian ini akan merumuskan suatu strategi pemenuhan kebutuhan SDM perbankan syariah yang berguna bagi industri, regulator, maupun pihak-pihak terkait.

Begitu juga untuk menghadapi persaingan sekarang ini perbakan syariah harus memiliki Sumber daya manusia yang berkualitas. Sumber daya manusia dalam organisasi merupakan aspek krusial yang menentukan keefektifan suatu organisasi. Oleh karena itu organisasi senantiasa perlu melakukan investasi dengan melaksanakan fungsi manajemen sumber daya manusia yaitu mulai perekrutan, penyeleksian sampai mempertahankan sumber daya manusia. Akan tetapi fenomena yang sering terjadi adalah manakala kinerja perusahaan telah baik dapat rusak baik secara langsung maupun tidak langsung oleh berbagai perilaku karyawan.

Salah satu bentuk perilaku karyawan tersebut adalah intensi perputaran (turn-over intentions) yang dapat berujung pada keputusan karyawan meninggalkan pekerjaannya. Intensi perputaran (turn-over intentions) dapat diartikan yaitu pergerakan tenaga kerja keluar dari organisasi. Turn-over dapat berupa pengunduran diri, perpindahan keluar unit organisasi, pemberhentian, atau kematian anggota organisasi. Tingkat turnover yang tinggi akan menimbulkan dampak negatif bagi organisasi, hal ini seperti menciptakan 
ketidakstabilan dan ketidakpastian (uncertainity) terhadap kondisi tenaga kerja dan peningkatan biaya sumber daya manusia yakni yang berupa biaya pelatihan yang sudah diinvestasikan pada karyawan sampai biaya rekrutmen dan pelatihan kembali.

Menurut Harninda (1999): "Turnover intentions pada dasarnya adalah sama dengan keinginan berpindah karyawan dari satu tempat kerja ke tempat kerja lainnya." Pendapat tersebut menunjukkan bahwa turnover intentions adalah keinginan untuk berpindah, belum sampai pada tahap realisasi yaitu melakukan perpindahan dari satu tempat kerja ke tempat kerja lainnya. Harnoto (2002:2) menyatakan: "turnover intentions adalah kadar atau intensitas dari keinginan untuk keluar dari perusahaan, banyak alasan yang menyebabkan timbulnya turnover intentions ini dan diantaranya adalah keinginan untuk mendapatkan pekerjaan yang lebih baik." Pendapat tersebut juga relatif sama dengan pendapat yang telah diungkapkan sebelumnya, bahwa turnover intentions pada dasarnya adalah keinginan untuk meninggalkan (keluar) dari perusahaan.

Turnover yang tinggi juga mengakibatkan organisasi tidak efektif karena perusahaan kehilangan karyawan yang berpengalaman dan perlu melatih kembali karyawan baru. Saat ini tingginya tingkat perputaran karyawan telah menjadi masalah serius bagi banyak perusahaan, bahkan beberapa perusahaan mengalami frustasi ketika mengetahui proses rekrutmen yang telah berhasil menjaring staf yang berkualitas pada akhirnya ternyata menjadi sia-sia karena staf yang direkrut tersebut telah memilih pekerjaan di perusahaan lain (Toly, 2006). Dengan tingginya tingkat perputaran pada perusahaan akan semakin banyak menimbulkan berbagai potensi biaya baik itu biaya pelatihan yang sudah diinvestasikan pada karyawan, tingkat kinerja yang mesti dikorbankan, maupun biaya rekrutmen dan pelatihan kembali (Suwandi dan Indriantoro, 2009).

Intensi perputaran yang tinggi menyita perhatian perusahaan karena mengganggu operasi, melahirkan permasalahan moral pada karyawan yang tinggal, dan juga melambungkan biaya dalam rekrutmen, wawancara, tes, pengecekan referensi, biaya administrasi pemrosesan karyawan baru, 
tunjangan, orientasi, dan biaya peluang yang hilang karena karyawan baru harus mempelajari keahlian yang baru (Simamora, 2010). Tingginya tingkat perputaran tenaga kerja dapat diprediksi dari seberapa besar keinginan berpindah yang dimiliki anggota suatu organisasi atau perusahaan. Penelitianpenelitian dan literatur yang ada menunjukkan bahwa keinginan berpindah seseorang terkait erat dengan kepuasan gaji, kepuasan kerja dan komitmen organisasional.

Pergantian karyawan atau keluar masuknya karyawan dari organisasi adalah suatu fenomena penting dalam kehidupan organisasi. Ada kalanya pergantian karyawan memiliki dampak positif. Namun sebagian besar pergantian karyawan membawa pengaruh yang kurang baik terhadap organisasi, baik dari segi biaya maupun dari segi hilangnya waktu dan kesempatan untuk memanfaatkan peluang Dalam arti luas, "turnover diartikan sebagai aliran para karyawan yang masuk dan keluar perusahaan" (Ronodipuro dan Husnan, 1995). Sedangkan Mobley (1999), mengemukakan bahwa batasan umum tentang pergantian karyawan adalah: "berhentinya individu sebagai anggota suatu organisasi dengan disertai pemberian imbalan keuangan oleh organisasi yang bersangkutan".

Menurut Mobley (1977) pada Judge (1993), keinginan untuk mengakhiri tugas atau meninggalkan organisasi berhubungan negatif dengan kepuasan kerja. Kepuasan kerja yang dirasakan dapat mempengaruhi pemikiran seseorang untuk keluar. Evaluasi terhadap berbagai alternatif pekerjaan, pada akhirnya akan mewujudkan terjadinya perputaran karena individu yang memilih keluar organisasi akan mengharapkan hasil yang lebih memuaskan di tempat lain.

Alasan untuk mencari pekerjaan alternatif lain di antaranya adalah kepuasan atas gaji yang diterima. Individu merasakan adanya rasa keadilan terhadap gaji yang diterima sehubungan dengan pekerjaan yang dilakukannya. Kepuasan gaji dapat diartikan bahwa seseorang akan terpuaskan dengan gajinya ketika persepsi terhadap gaji dan apa yang mereka peroleh sesuai dengan yang diharapkan. 
Kepuasan kerja juga dihubungkan negatif dengan keluarnya karyawan (turnover intention) tetapi faktor-faktor lain seperti kondisi pasar kerja, kesempatan kerja alternatif, dan panjangnya masa kerja merupakan kendala yang penting untuk meninggalkan pekerjaan yang ada (Robbins, 2004; Tett and Meyer, 2005; Johnson et. al, 2003). Individu yang merasa terpuaskan dengan pekerjaannya cenderung untuk bertahan dalam organisasi. Sedangkan individu yang merasa kurang terpuaskan dengan pekerjaannya akan memilih untuk keluar dan organisasi. Kepuasan kerja yang dirasakan dapat mempengaruhi pemikiran seseorang untuk keluar. Evaluasi terhadap berbagai alternatif pekerjaan, pada akhirnya akan mewujudkan terjadinya perputaran karena individu yang memilih keluar organisasiakan mengharapkan hasil yang lebih memuaskan di tempat lain.

Penelitian yang dilakukan Meyer et al. (2005) mendukung bahwa peningkatan komitmen berhubungan dengan peningkatan produktivitas dan perputaran yang semakin rendah. Komitmen organisasional memberikan kontribusi dalam memprediksi variabel-variabel penting organisasi yang berhubungan dengan keluaran (misalnya: intensi keluar). Variabel keluaran yang diuji pada penelitian ini berhubungan dengan keinginan individu untuk keluar dari organisasi dan sampel yang digunakan adalah karyawan Perbankan Syariah di Kota Batam. Meyer et.al (2005) juga menyimpulkan bahwa komitmen organisasional berhubungan signifikan dengan keinginan individu untuk keluar jabatan dan aktifitas dalam organisasi. Pekerja-pekerja dengan komitmen afektif yang kuat akan tetap berada dalam organisasi karena mereka merasakan bahwa mereka sebaiknya bekerja demikian (Johson et al., 2007; Tettand Meyer, 2006; Lum et al., 2008).

Menurut hasil penelitian Shore dan Martin (1989) dan Muller dan Price (1990), yang dikutip dari Lum, et al. (2008), menyimpulkan bahwa kepuasan kerjadan komitmen berhubungan dengan perputaran, walaupun demikian komitmen organisasional lebih mempunyai hubungan yang kuat terhadap intensi keluar, berarti bahwa kepuasan kerja merupakan variabel mendahului komitmen organisasional. Komitmen organisasional merupakan prediktor yang kuat bagi voluntary turnover. Adanya kecenderungan komitmen (commiment 
prospensity) sebelum memasuki organisasi akan berhubungan positif dengan komitmen awal (sebelum memasuki organisasi) dan komitmen berikutnya (setelah masuk organisasi) akan berhubungan negatif dengan voluntary turnover (Lee et al., 2007), sehingga kepuasan kerja karyawan akan dipengaruhi oleh komitmen pada tahap awal memasuki organisasi (Lance and Vandenberg, 2005).

Tingkat perputaran karyawan yang tinggi merupakan ukuran yang sering digunakan sebagai indikasi adanya masalah yang mendasar pada organisasi. Perputaran karyawan dapat menelan biaya yang tinggi oleh karena itu organisasi perlu menguranginya sampai pada tingkat-tingkat yang dapat diterima. Namun demikian, mempertahankan tingkat perputaran sebesar nol adalah tidak realistis dan bahkan tidak dikehendaki. Jumlah perputaran tertentu adalah diperlukan karena para karyawan mengembangkan keahlian-keahlian baru dan dipromosikan ke tingkat tanggung jawab yang lebih besar.

Penelitian sebelumnya yang menguji hubungan antara komitmen, kepuasan kerja dan intensi keluar mendukung bahwa komitmen lebih memiliki pengaruh penting terhadap keinginan untuk keluar dari organisasi, sehingga kepuasan kerja dipandang sebagai antecendent komitmen organisasional (William\& Hazer, 1986). Model lain yang dikemukakan Bateman \& Strasser (1984) pada Crammer (2006) menyatakan bahwa kepuasan kerja bukan penyebab komitmen organisasional, tetapi merupakan akibat, dengan kata lain komitmen merupakan antecendent dari kepuasan kerja. Penelitian ini dilakukan untuk menguji pengaruh kepuasan gaji, kepuasan kerja, komitmen organisasional terhadap intensi keluar.

\section{METODE}

Obyek penelitian ini adalah seluruh Perbankan Syariah di Kota Batam, baik berupa Bank Umum maupun Bank Perkreditan Rakyat yang terdaftar di Otoritas Jasa Keuangan per Januari 2015. Penelitian ini terfokus pada bidang Manajemen Sumber Daya Manusia khususnya pada Kepuasan Kerja, Reward, Komitmen Organisasi dan intensi perputaran. Peneliti akan menganalisa Kepuasan Kerja sebagai variabel intervening Komitmen Organisasi dan penghargaan pada Perbankan Syariah di Wilayah Batam. 
Metode penelitian yang digunakan adalah studi analisis konfirmatori dengan mengemukakan fakta-fakta yang terjadi di lapangan yang bertujuan untuk memperoleh data sekunder yang berkaitan dengan dengan tinjauan pustaka dan data-data tentang perusahaan. Sugiyono (2009) menjelaskan, "Populasi adalah wilayah generalisasi yang terdiri atas: obyek atau subyek yang mempunyai kualitas dan karakteristik tertentu yang ditetapkan oleh peneliti untuk dipelajari dan kemudian ditarik kesimpulannya”.

Dalam penelitian ini populasi yang digunakan adalah karyawan organik perbankan syariah yang ada di Kota Batam, karena untuk karyawan non organik biasanya sudah disediakan oleh vendor outsourching. Jumlah sample direncanakan 176 orang, namun pada saat penelitian sampel yang bisa digunakan 134 responden. Pengumpulan data dilakukan dengan menggunakan kuesioner yaitu suatu metode pengumpulan data dengan memberikan atau menyebarkan daftar pertanyaan kepada responden. Setiap responden diminta pendapatnya dengan memberikan jawaban dari pernyataan-pernyataan yang diajukan.

Teknik analisis yang dipergunakan dalam penelitian ini adalah menggunakan analisis lajur. Analisis jalur adalah suatu teknik pengembangan dari regresi linier ganda.Teknik ini digunakan untuk menguji besarnya sumbangan (kontribusi) yang ditunjukkan oleh koefisien jalur pada setiap diagram jalur dari hubungan kausal antar variabel $\mathrm{X}_{1} \mathrm{X}_{2}$ dan $\mathrm{X}_{3}$ terhadap $\mathrm{Y}$ serta dampaknya terhadap Z. "Analisis jalur ialah suatu teknik untuk menganalisis hubungan sebab akibat yang tejadi pada regresi berganda jika variabel bebasnya mempengaruhi variabel tergantung tidak hanya secara langsung tetapi juga secara tidak langsung" (Retherford 1993). Sedangkan definisi lain mengatakan: "Analisis jalur merupakan pengembangan langsung bentuk regresi berganda dengan tujuan untuk memberikan estimasi tingkat kepentingan (magnitude) dan signifikansi (significance) hubungan sebab akibat hipotetikal dalam seperangkat variabel." (Webley, 1997).

Adapun variabel yang dipergunakan ialah komitmen organisasional $\left(\mathrm{X}_{1}\right)$ dan penghargaan $\left(\mathrm{X}_{2}\right)$ dengan variabel moderator adalah kepuasan kerja $\left(\mathrm{X}_{3}\right)$, serta variabel intensi perputaran sebagai variabel terikat (Y). Dalam 
penelitian ini ada beberapa hal yang akan dianalisis, yaitu: apakah komitmen organisasional dan penghargaan secara individu berpengaruh terhadap kepuasan kerja. Kemudian apa pengaruh kepuasan kerja terhadap intensi perputaran. Serta apakah ada pengaruh komitmen organisasional dan penghargaan secara individu terhadap intensi perputaran. Selanjutnya apakah komitmen organisasional dan penghargaan berpengaruh terhadap intensi perputaran melalui kepuasan kerja.

\section{Gambar 1. Kerangka Penelitian}

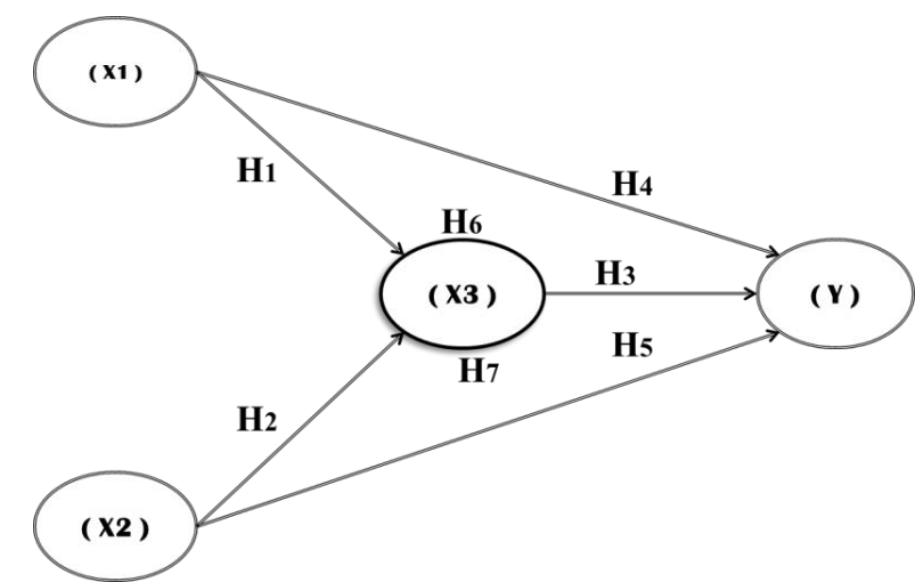

\section{PEMBAHASAN}

Berdasarkan hasil pengujian tujuh hipotesis yang diajukan dalam penelitian ini hanya empat hipotesis yang dapat diterima. Berikut akan dibahas atas hasil pengujian ketujuh hipotesis tersebut. Pertama, berdasarkan hasil analisis jalur Komitmen Organisasional $\left(\mathrm{X}_{1}\right)$ terhadap Kepuasan Kerja $\left(\mathrm{X}_{3}\right)$ diperoleh koefisien jalur sebesar 0,443 dengan $t_{\text {hitung }}=6,749$ sedangkan nilai $t_{\text {tabel }}=1,656(\alpha=0,05)$, karena $t_{\text {hitung }}>t_{\text {tabel }}$, maka dapat disimpulkan bahwa koefisien jalur signifikan. Dengan terbuktinya hipotesis pertama ini yang menyatakan terdapat pengaruh langsung Komitmen Organisasional terhadap Kepuasan Kerja, maka dapat diindikasikan apabila ingin meningkatkan Kepuasan Kerja pegawai dapat dilakukan dengan peningkatan Komitmen Organisasional pegawai. Peningkatan Komitmen Organisasional ini dapat melalui pendidikan atau pelatihan pengembangan diri dan menerapkannya dalam kepemimpinan maupun dalam berinteraksi dengan sesama pegawai di dalam perusahaan. 
Kedua, berdasarkan hasil analisis jalur penghargaan $\left(\mathrm{X}_{2}\right)$ terhadap Kepuasan Kerja $\left(\mathrm{X}_{3}\right)$ diperoleh koefisien jalur sebesar 0,545 dengan $t_{\text {hitung }}=$ 8,314 sedangkan nilai $t_{\text {tabel }}=1,656(\alpha=0,05)$, karena $t_{\text {hitung }}>t_{\text {tabel, }}$ maka dapat disimpulkan bahwa koefisien jalur signifikan. Dengan terbuktinya hipotesis kedua ini yang menyatakan terdapat pengaruh langsung penghargaan terhadap kepuasan kerja, maka dapat diindikasikan apabila ingin meningkatkan Kepuasan kerja pegawai dapat dilakukan dengan peningkatan penghargaan terhadap pegawai. Penghargaan dapat berupa pengakuan atas prestasi kerja, penataan administrasi penggajian, adanya jenjang karir yang jelas, jaminan kesehatan karyawan dan sebagainya.

Ketiga, hasil analisis jalur kepuasan kerja $\left(\mathrm{X}_{3}\right)$ terhadap intensi perputaran $(\mathrm{Y})$ diperoleh koefisien jalur langsung sebesar 0,972 dengan $t_{\text {hitung }}=$ 9.687 sedangkan nilai $t_{\text {tabel }}=1,656(\alpha=0,05)$, karena $t_{\text {hitung }}>t_{\text {tabel, }}$ maka dapat disimpulkan bahwa koefisien jalur signifikan. Dengan terbuktinya hipotesis ketiga ini yang menyatakan terdapat pengaruh langsung Kepuasan Kerja terhadap intensi perputaran, maka dapat diindikasikan apabila ingin meningkatkan kepuasan kerja pegawai dapat dilakukan dengan memberikan kesempatan karyawan dalam pembangan potensi diri, pengembangan karir berdasarkan kinerja dan peningkatan kepuasan terhadap kenyaman dalam bekerja. Lingkungan kerja yang kondusif akan mendukung pegawai dalam menjalankan aktivitasnya sehingga merasa puas dalam bekerja dan akan memperkecil intensi perputaran dari pegawai.

Keempat, berdasarkan hasil analisis jalur Komitmen Organisasional $\left(\mathrm{X}_{1}\right)$ terhadapTurn-over Intention (Y) diperoleh koefisien jalur langsung sebesar 0,763 dengan $t_{\text {hitung }}=4.067$ sedangkan nilai $t_{\text {tabel }}=1,656(\alpha=0,05)$, karena $t_{\text {hitung }}>t_{\text {tabel. }}$. Dengan terbuktinya hipotesis keempati ni yang menyatakan terdapat pengaruh langsung Komitmen Organisasi terhadap intensi perputaran, maka dapat diindikasikan apabila ingin mengurangi intense keluar dari pegawai dapat dilakukan dengan peningkatan Komitmen Organisasi. Membangun komunikasi antara atasan dan bawahan, menyelanggarakan acara kebersamaan, menyampaikan visi dan misi perusahaan adalah beberapa cara untuk meningkatkan komitmen organisasi. 
Kelima, hasil analisis jalur penghargaan $\left(\mathrm{X}_{2}\right)$ terhadap intensi perputaran (Y) diperoleh koefisien jalur langsung sebesar 0,127 dengan thitung= 2.475 sedangkan nilai $t_{\text {tabel }}=1,656(\alpha=0,05)$, karena $t_{\text {hitung }}>t_{\text {tabel, }}$, maka dapat disimpulkan bahwa koefisien jalur signifikan. Hipotesis kelima ini menunjukkan terdapat pengaruh langsung secara signifikan penghargaan terhadap intensi perputaran. Dengan hasil uji tersebut maka dapat diindikasikan apabila ingin mengurangi intensitas keluar dari karyawan terlebih dahulu meningkatkan penghargaan pegawai. Misalnya pemberian insentif kepada pegawai, pemberian bonus atas prestasi kerja perusahaan dan sebagainya.

Keenam, berdasarkan hasil analisis jalur Komitmen Organisasional $\left(\mathrm{X}_{1}\right)$ terhadap intensi perputaran $(\mathrm{Y})$ melalui Kepuasan Kerja $\left(\mathrm{X}_{3}\right)$ diperoleh koefisien jalur tidak langsung sebesar 0,036 dengan $t_{\text {hitung }}=0,215$ sedangkan nilai $t_{\text {tabel }}=1,661(\alpha=0,05)$ dan 2,367 $(\alpha=0,01)$, karena $t_{\text {hitung }}>t_{\text {tabel, }}$, maka dapat disimpulkan bahwa koefisien jalur signifikan. Hipotesis keenam ini menunjukkan terdapat pengaruh tidak langsung secara signifikan Komitmen Organisasional terhadap intensi perputaran melalui Kepuasan Kerja. Dengan hasil uji tersebut maka dapat diindikasikan apabila ingin mengurangi intensitas keluar dari pegawai terlebih dahulu meningkatkan kepuasan kerja pegawai melalui penataan ulang pekerjaan seperti melalui penempatan pegawai sesuai dengan keahlian atau latarbelakang pendidikan, menciptakan keragaman tugas, dan memberikan kesempatan kepada pegawai untuk merencanakan atau menyelesaikan pekerjaannya secara mandiri.

Ketujuh, berdasarkan hasil analisis jalur penghargaan $\left(\mathrm{X}_{2}\right)$ terhadap intensi perputaran $(\mathrm{Y})$ melalui Kepuasan Kerja $\left(\mathrm{X}_{3}\right)$ diperoleh koefisien jalur tidak langsung sebesar 0,124 dengan $t_{\text {hitung }}=2.475$ sedangkan nilai $t_{\text {tabel }}=1,656$ $(\alpha=0,05)$, karena $t_{\text {hitung }}>t_{\text {tabel, }}$ maka dapat disimpulkan bahwa koefisien jalur signifikan. Hipotesis tujuh ini menunjukkan terdapat pengaruh tidak langsung secara signifikan penghargaan terhadap intensi perputaran melalui Kepuasan Kerja. Dengan hasil uji tersebut maka dapat diindikasikan apabila ingin mengurangi intensitas keluar dari pegawai terlebih dahulu meningkatkan kepuasan kerja pegawai melalui penciptaan suasana kantor yang kondusif baik sarana maupun prasana sehingga pegawai merasa nyaman dalam bekerja. 
Berdasarkan hasil yang didapat menunjukkan bahwa komitmen organisasional dan penghargaan akan mempengaruhi kepuasan kerja. Akibat dari kepuasan kerja yang semakin meningkat akan mampu menurunkan intensi perputaran dari karyawan, sehingga karyawan akan lebih setia dan meningkatkan kinerja yang diharapkan oleh perusahaan.

Waspodo, dkk (2013) menemukan bahwa kepuasan kerja memiliki pengaruh negatif terhadap perputaran karyawan, dan stres kerja memiliki pengaruh positif terhadap perputaran karyawan di PT Unitex di Bogor. Selain itu kepuasan kerja dan stress kerja secara bersama-sama memiliki pengaruh terhadap perputaran karyawan. Perputaran karyawan di PT Unitex mampu dijelaskan oleh kepuasan kerja dan stres kerja sebesar $45.1 \%$ dan sisanya sebesar 54.9\% dijelaskan olef variabel lain d luar model.

Simanjutak (2013) dalam penelitiannya yang bertujuan untuk melihat pengaruh keterlibatan kerja dan kepuasan kerja terhadap perputaran karyawan di PT Njonja Meneer Semarang. Hasil pengujian menunjukkan bahwa keterlibatan kerja berpengaruh negatif dan signifikan terhadap perputaran karyawan dan kepuasan karyawan berpengaruh negatif dan signifikan terhadap perputaran karyawan. Hasil koefisien determinasi sebesar 0.482 menunjukkan bahwa kemampuan variabel independen (keterlibatan kerja dan kepuasan kerja) dalam menjelaskan variabel dependen sebesar 48.2\%.

Sidharta dan Margaretha (2011) menyatakan bahwa kepuasan kerja dan komitmen organisasi secara bersama-sama berpengaruh terhadap perputaran karyawan. Sedangkan kepuasan kerja dan komitmen organisasi memiliki hubungan yang negatif secara individu terhadap perputaran karyawan. Hal ini menunjukkan bahwa konsistensi komitmen organisasi dalam memprediksi keinginan karyawan untuk keluar dari organisasi.

Oleh karenanya ada beberapa hal yang dapat disarankan dari penelitian ini, yaitu: pertama, para pemimpin perbankan syariah di wilayah Batam hendaknya memperhatikan aspek-aspek komitmen organisasi, penghargaan karena akan berdampak pada kepuasan kerja, dan kepuasan kerja pada karyawan akan berdampak pada intensi perputaran di perusahaan. Kedua, sistem kompensasi dan benefit lainnya, perlu didesain sedemikian rupa untuk 
disesuaikan dengan kebutuhan individu dan organisasi. Dengan hal tersebut diharapkan akan meningkatkan komitmen organisasional pada karyawan. Ketiga, meningkatkan kesadaran kepada karyawan bahwa karyawan memiliki peran yang sangat penting dalam memajukan perusahaan, hal ini senantiasa diingatkan oleh para pemimpin perusahaan. Keempat, dalam melakukan sistem penggajian, hendaknya dilakukan secara adil, maksudnya yaitu gaji yang dibayarkan sesuai dengan kompetensi, keahlian dan pekerjaan dan mempunyai nilai kompetitif di pasar. Kelima, Memberikan kesempatan kepada karyawannya untuk mengembangkan ide dalam menyelesaikan pekerjaannnya. Keenam, Praktek dan kebijakan promosi yang dilakukan perusahaan hendaknya bersifat adil bukan berdasarkan subjektivitas, karena promosi memberikan peningkatan pribadi, tanggung jawab dan status. Individu yang merasa bahwa keputusan promosi yang telah ada berlaku dengan baik akan berpengaruh terhadap kepuasan kerjanya.

\section{SIMPULAN}

Berdasarkan hasil analisis data, pengujian hipotesis dan hasil temuan deskriptif dari kuesioner dengan jumlah sample yang bisa diolah pegawai Perbankan Syariah di Wilayah Kota Batam sebanyak 134 orang, maka dapat disimpulkan sebagai berikut: Hasil pengujian menunjukkan terdapat pengaruh langsung secara signifikan Komitmen Organisasional terhadap Kepuasan Kerja. Hasil pengujian menunjukkan terdapat pengaruh langsung secara signifikan penghargaan terhadap Kepuasan Kerja. Hasil pengujian menunjukkan terdapat pengaruh langsung secara signifikan Kepuasan Kerja terhadap intensi perputaran. Hasil pengujian menunjukkan terdapat pengaruh langsung secara signifikan Komitmen Organisasi terhadap intensi perputaran. Hasil pengujian menunjukkan terdapat pengaruh langsung secara signifikan penghargaan terhadap intensi perputaran. Hasil pengujian menunjukkan terdapat pengaruh tidak langsung secara signifikan Komitmen Organisasional terhadap intensi perputaran melalui Kepuasan Kerja. Hasil pengujian menunjukkan terdapat pengaruh tidak langsung secara signifikan penghargaan terhadap intensi perputaran melalui Kepuasan Kerja. 
Kemudian saran bagi penelitian selanjutnya ialah: pertama, dapat mendorong dan memicu dilakukannya penelitian-penelitian berikutnya pada bidang manajemen sumber daya manusia dengan menggunakan variabelvariabel lain yang belum dimasukan dalam penelitian ini, misalnya kepemimpinan, iklim kerja dan fasilitas kerja. Kedua, diharapkan memperbanyak jumlah responden dan dapat menggunakan metode wawancara dalam mendapatkan data yang valid dan menggambarkan kondisi sesungguhnya

\section{PUSTAKA ACUAN}

Abelson, M. A. 2007. Examination of Avoidable and Unavoidable Turnover. Journal of Applied Phsychology, 72, pp. 381-386

Arianto, A.T. 2006. Analisis faktor-Faktor yang Mempengaruhi Turnover Intention pada Staff Kantor Akuntan Publik. Jurnal Akuntansi dan Keuangan. Vol. 3 (1), hlm. 102-125

Elfenbein, H.A \& A. Charles. 2007. Fitting in: The Edffect of Relational Demography and Person Culture Fit on Group Process and Performance. Journal of Group \& Organization. Vol. 32, pp. 51-62

Handoko, H. 2008. Manajemen Personalia dan Sumber Daya Manusia. Yogyakarta: BPFE. Yogyakarta.

Hasibuan. 2006. Manajemen Sumber Daya Manusia. Jakarta: Bumi Aksara.

Hair, J. F. et. al. 2005. Multivariate Data Analysis with Reading. New Jersey: Prentice-Hall International.

Jantje, E.L. 2009. Hubungan Profesionalisme dengan konsekuensinya : Komitmen Organisasional, Kepuasan Kerja, Prestasi Kerja dan Keinginan Berpindah (Studi Empiris di Lingkungan Akuntan Publik). Jurnal Bisnis dan Akuntansi. Vol.5 No.1, hlm. 69-84.

Lum, L. et. al. 2008. Explaining Nursing Turnover Intent : Job Satisfaction, Pay Satisfaction, or Organizational Commitment. Journal of Organizational Behavior. Vol. 19, pp. 305- 320

Marzuki. 2005. Metodologi Riset. Yogyakarta: BPFE - UII Yogyakarta.

Mathis, R.L. \& J. Jackson. 2010. Manajemen Sumber Daya Manusia. Jakarta: PT. Salemba Empat. 
Meyer, JP \& N.J. Allen. 2010. A Three Component Conceptualization of organizational Commitment. Human Resource Management Review, Vol. 4 (1), pp. 71 - 84

Mottaz J, Clifford. 2008. Determinants of Organizational Commitment. Human Relations, Vol 41 (6), pp 467 - 482

Pantja, S.D. \& M. Khuaini. 2006. Kajian Terhadap Kepuasan Kompensasi, Komitmen Organisasi, dan Prestasi Kerja. Jurnal Manajemen \& Kewirausahaan Vol 5, No 1, hlm. 25-41

Parasdya, H. 2012. Pengaruh Kompensasi Terhadap Kepuasan Kerja Karyawan PD BPR BKK Boyolali Kota. (Skripsi Tidak Dipublikasikan). Yogyakarta: Universitas Kristen Satya Wacana

Rivai, H.A. 2006. Pengaruh Kepuasan Gaji, Kepuasan Kerja dan Komitmen Organisasional terhadap Intensi Keluar. Jurnal Bisnis dan Akuntansi. Vol. 1 No.1, hlm. 335-352.

Robbins, S. 2010. Perilaku Organisasi. Jakarta: PT.Prehalindo.

Rumengan, J. 2013. Metodologi Penelitian. Bandung: Citapustaka Media Perintis Santoso, R.P. 2012. Ekonomi Sumber Daya Manusia dan Ketenagakerjaan. Yogyakarta: UPP STIM YKPN.

Setiawan, H. 2009. Pengaruh Komitmen Organisasional Terhadap Kepuasan Kerja Dengan Organizational Citizenship Behavior (Ocb) Sebagai Variabel Intervening (Studi Pada Inspektorat Kabupaten Temanggung). (Tesis Tidak Dipublikasikan). Semarang: Universitas Diponegoro Sidharta, N \& M. Margaretha. 2011. Dampak Komitmen Organisasi dan Kepuasan Kerja Terhadap Turnover Intention: Studi Empiris pada Bagian Operator di Salah Satu Perusahaan Garment di Cimahi. Jurnal Manajemen, Vol. 10, No. 2, hlm. 129 - 142

Simamora, H. 2010. Manajemen Sumber Daya Manusia. Yogyakarta: STIE YKPN. Simanjutak, N. 2013. Analisis Pengaruh Keterlibatan Kerja dan Kepuasan Kerja Terhadap Turnover Intention Karyawan: Studi Pada PT Njonja Meneer Semarang. (Skripsi Tidak Dipublikasikan). Semarang: Universitas Diponegoro.

Siagian, S. 2013. Manajemen Sumber Daya Manusia. Jakarta: Bumi Aksara. 
Sopiah. 2008. Perilaku Organisasional. Yogyakarta : Penerbit Andi

Sugiyono. 2009. Metode Penelitian Administrasi. Bandung: CV. Alfabeta

Suwandi \& N. Indriantoro. 2009. Pengujian Model Turnover Pasewark dan Strawser: Studi Empiris pada Lingkungan Akuntansi Publik. Jurnal Riset Akuntansi Indonesia, Vol. 2, hlm. 173-195.

Syafrizal, G.D. 2011. Analisa Pengaruh Kepuasan Kerja Terhadap Turnover Intention Serta Dampaknya Terhadap Karyawan Hotel Horison Semarang. (Skripsi Tidak Dipublikasikan). Semarang: Universitas Diponegoro.

Waspodo, A. AWS, dkk. 2013. Pengaruh Kepuasan Kerja dan Stres Kerja Terhadap Turnover Intention Pada Karyawan PT Unitex di Bogor. Jurnal Riset Manajemen Sains Indonesia, Vol. 4, No. 1, hlm. 97 -115 